University of Nebraska - Lincoln

DigitalCommons@University of Nebraska - Lincoln

Publications from USDA-ARS / UNL Faculty

U.S. Department of Agriculture: Agricultural

Research Service, Lincoln, Nebraska

2012

\title{
A national survey of managed honey bee 2010-11 winter colony losses in the USA: results from the Bee Informed Partnership
}

\author{
Dennis vanEngelsdorp \\ University of Maryland, dennis.vanengelsdorp@gmail.com \\ Dewey Caron \\ Oregon State University \\ Jerry Hayes \\ Bureau of Plant and Apiary Inspection \\ Robyn Underwood \\ Kutztown University \\ Mark Henson \\ Appalachian State University \\ See next page for additional authors
}

Follow this and additional works at: https://digitalcommons.unl.edu/usdaarsfacpub

vanEngelsdorp, Dennis; Caron, Dewey; Hayes, Jerry; Underwood, Robyn; Henson, Mark; Rennich, Karen; Spleen, Angela; Andree, Michael; Snyder, Robert; Lee, Kathleen; Roccasecca, Karen; Wilson, Michael; Wilkes, James; Lengerich, Eugene; and Pettis, Jeffrey S., "A national survey of managed honey bee 2010-11 winter colony losses in the USA: results from the Bee Informed Partnership" (2012). Publications from USDA-ARS / UNL Faculty. 1585.

https://digitalcommons.unl.edu/usdaarsfacpub/1585

This Article is brought to you for free and open access by the U.S. Department of Agriculture: Agricultural Research Service, Lincoln, Nebraska at DigitalCommons@University of Nebraska - Lincoln. It has been accepted for inclusion in Publications from USDA-ARS / UNL Faculty by an authorized administrator of DigitalCommons@University of Nebraska - Lincoln. 


\section{Authors}

Dennis vanEngelsdorp, Dewey Caron, Jerry Hayes, Robyn Underwood, Mark Henson, Karen Rennich, Angela Spleen, Michael Andree, Robert Snyder, Kathleen Lee, Karen Roccasecca, Michael Wilson, James Wilkes, Eugene Lengerich, and Jeffrey S. Pettis 


\title{
A national survey of managed honey bee 2010-11 winter colony losses in the USA: results from the Bee Informed Partnership
}

\author{
Dennis vanEngelsdorp ${ }^{1 *}$, Dewey Caron ${ }^{2}$, Jerry Hayes ${ }^{3}$, Robyn Underwood ${ }^{1,4}$, Mark Henson ${ }^{5}$, Karen \\ Rennich $^{1}$, Angela Spleen ${ }^{6}$, Michael Andree ${ }^{7}$, Robert Snyder ${ }^{7}$, Kathleen Lee', Karen Roccasecca ${ }^{1}$, \\ Michael Wilson ${ }^{8}$, James Wilkes ${ }^{5}$, Eugene Lengerich ${ }^{6}$, Jeffery Pettis ${ }^{9}$, for the Bee Informed Partnership ${ }^{10}$
}

${ }^{1}$ Department of Entomology, University of Maryland, College Park, MD 20742, USA.

${ }^{2}$ Department of Horticulture, Oregon State University, Corvallis, OR 97301, USA.

${ }^{3}$ Florida Department of Agriculture, Bureau of Plant and Apiary Inspection, Apiary Inspection Section, Division of Plant Industry, P.O. Box 147100, Gainesville, FL 32614, USA.

${ }^{4}$ Department of Biology, Kutztown University, Kutztown, PA 19530, USA.

${ }^{5}$ Department of Computer Science, Appalachian State University, Boone, NC 28608, USA.

${ }^{6}$ Department of Public Health Sciences, The Pennsylvania State University, 600 Centerview Dr. Suite 2200 Mailstop A210, Hershey, PA 17033, USA.

7University of California, Cooperative Extension Butte County, 2279-B Del Oro Avenue Oroville, CA 95965, USA.

${ }^{8}$ Department of Entomology and Plant Pathology, University of Tennessee, 205 Ellington Plant Science Bldg., Knoxville, TN 37996, USA.

${ }^{9}$ USDA - ARS Bee Research Laboratory, Bldg. 476 BARC-E, Beltsville, MD 20705, USA.

${ }^{10}$ www.beeinformed.org

Received 7 October 2011, accepted subject to revision 6 December 2011, accepted for publication 10 January 2012.

*Corresponding author: Email: dennis.vanengelsdorp@gmail.com

\section{Summary}

This study records the fifth consecutive year that winter losses of managed honey bee (Apis mellifera) colonies in the USA have been around $30 \%$. In April 2011, a total of 5,441 US beekeepers (an estimated $11 \%$ of total US beekeepers) responded to a survey conducted by the Bee Informed Partnership. Survey respondents reported that they had lost an average of $38.4 \%$ of their colonies, for a total US colony loss of 29.9\% over the winter of 2010-11. One-third of respondents (all classified as backyard beekeepers, i.e. keeping fewer than 50 colonies) reported no winter loss. There was considerable variation in both the average and total loss by state. On average, beekeepers consider acceptable losses to be $13.2 \%$, but $68 \%$ of all responding beekeepers suffered actual losses in excess of what they considered acceptable. Of beekeepers who reported losing at least one colony, manageable conditions, such as starvation and a weak condition in the fall, were the leading self-identified causes of mortality. Respondents who indicated that varroa mites (Varroa destructor), small hive beetles (Aethina tumida), poor wintering conditions, and / or Colony Collapse Disorder (CCD) conditions were a leading cause of mortality in their operations suffered a higher average loss than beekeepers who did not list any of these as potential causes. In a separate question, beekeepers who reported the symptom "no dead bees in hive or apiary" had significantly higher losses than those who did not report this symptom. In addition, commercial beekeepers were significantly more likely to indicate that colonies died with this symptom than either backyard or sideliner beekeepers. 


\section{Una encuesta nacional sobre las pérdidas invernales de colonias manejadas de abejas melíferas 2010-11 en los}

\section{Estados Unidos: resultados de la Bee Informed Partnership}

\section{Resumen}

Este estudio registra por quinto año consecutivo que las pérdidas invernales de abejas manejadas (Apis mellifera) en Estados Unidos están en torno al 30\%. En abril del 2011, un total de 5,441 apicultores de los EE.UU. (se estima que el 11\% del total de apicultores de EE.UU.) respondieron a una encuesta realizada por la Bee Informed Partnership. Los encuestados indicaron que habían perdido un promedio de $38.4 \%$ de sus colonias, con una pérdida total de colonias en EE.UU. del 29.9\% durante el invierno de 2010-11. Un tercio de los encuestados (todos ellos clasificados como apicultores aficionados, es decir, con menos de 50 colonias) indicaron que no tuvieron pérdidas de invierno. Hubo una variación considerable tanto en la media como en el total de pérdidas por Estado. Por término medio, los apicultores consideran aceptables pérdidas del $13.2 \%$, sin embargo, el $68 \%$ de todos los apicultores encuestados sufrieron pérdidas reales superiores a lo que consideran aceptable. Entre los apicultores que informaron de la pérdida de al menos una colonia, las principales causas de mortalidad identificadas por ellos fueron condiciones de manejo, tales como el hambre o una condición débil de las abejas en el otoño. Los encuestados que indicaron como principales causas de mortalidad de sus colmenas a los ácaros de Varroa (Varroa destructor), los escarabajos de las colmenas (Aethina tumida), las malas condiciones de invernada y / o condiciones del Síndrome de Colapso de las Colmenas (SCC), sufrieron una pérdida media mayor que aquellos apicultores que no incluyeron ninguna de estas causas potenciales. En una cuestión aparte, los apicultores que indicaron el síntoma "sin abejas muertas en la colmena o apiario" tenían pérdidas muy superiores a aquellos que no registraron ese síntoma. Además, los apicultores comerciales fueron significativamente más propensos a indicar que las colonias morían con este síntoma que los apicultores aficionados o los apicultores semi-profesionales.

Keywords: Honey bee, overwinter, mortality, USA, 2010-11

\section{Introduction}

Over the last few years, high rates of overwintering mortality have been reported in honey bee (Apis mellifera) colonies in many European and North American countries (vanEngelsdorp et al., 2008, 2010, 2011a; Currie et al., 2010; Neumann and Carreck, 2010; Nguyen et al., 2010; Potts, 2010). In the US specifically, high overwintering losses of $32 \%, 36 \%, 29 \%$ and $34 \%$ for the winters of 2006-7, 2007-8, 2008-9, and 2009-10, respectively, have been reported (vanEngelsdorp et al., 2007, 2008, 2010, 2011a).

It is clear that these losses, verging on $30 \%$ or more annually have not resulted in a pronounced decrease in the total number of honey-producing colonies managed by US beekeepers in the subsequent summers (USDA-NASS, 2009). The USDA-NASS Bee and Honey Inquiry is a survey that estimates the total number of US honey producing colonies on an annual basis, for operations with more than five colonies. From 2008-10, an increase in total colonies has been recorded in the USDA-NASS Honey report starting from 2.34 million colonies (rounded) in 2008; to 2.50 million in 2009; and to 2.68 million in 2010 (USDA-NASS, 2009, 2010, 2011). This apparent discrepancy may be explained by beekeepers who, fearing heavy losses, overwinter excess colonies to ensure they will have enough colonies to meet spring's pollination demands (vanEngelsdorp and Meixner, 2010). Beekeepers can increase the number of colonies they manage by either purchasing package bees or splitting existing hives. In addition, development and management of nucleus colonies has become more widespread as a hedge against heavy losses. A recent survey of Pacific Northwest beekeepers revealed that in both 2008 and 2009, beekeepers replaced more colonies than they lost in the preceding winter (Caron et al., 2010). Another possible explanation for this discrepancy may be differences in survey methods and the respondent population.

Heavy losses cannot always be replaced by dividing colonies and buying packages, however. A decrease of 142,000 colonies from 2007 -8 is reflected in the 2009 USDA-NASS Honey report. This is the only decrease from the previous year recorded by USDA-NASS during the period between 2006 and 2010. This loss could have occurred during the winter of 2007-8 where the "winter loss survey" recorded colony losses for the same time period of around 36\%; the highest loss in four years of surveys (vanEngelsdorp et al., 2008).

The reason for the high level of losses is not completely understood. While annual overwintering loss surveys are not designed to identify factors responsible for losses, each survey has asked beekeepers to self-identify the reasons they believe high losses 
occurred. Among the most mentioned factors have been queen failure, starvation, and varroa (Varroa destructor) mites (vanEngelsdorp et al., 2007, 2008, 2010,2011a). Whilst not conclusive, these self-identified causes of mortality do suggest that a multitude of factors are contributing to colony mortality, and so suggest that efforts aimed to reduce losses will need to be as diverse as the causes.

In keeping with previous years' efforts, this survey's objective was to quantify the mortality of colonies in the USA over the winter of 2010-11. Here we report average and total colony losses for the country and by state, we compare the rate of loss by operation size, activity, and by the symptom of "no dead bees in the hive or apiary", and we quantify the prevalence of suspected reasons for loss as selfreported by survey respondents.

\section{Materials and methods}

An email soliciting responses to an online survey posted at InstantSurvey.com was sent to state apiarists $(n=42)$, presidents of national and state beekeeping organizations $(n=110)$, industry leaders $(n=125)$, honey bee brokers $(n=17$; for almond pollination in CA), online beekeeper list servers, and posted on web-forums. A total of 2,877 individual emails were sent to participants in previous years' surveys who had indicated a desire to be contacted in future years. In addition, 621 individual emails were sent to persons who had "signed up to participate" at the beeinformed.org web site. These emails encouraged beekeepers to forward the request to other beekeepers. As in previous years, a number of large commercial beekeepers were contacted by telephone, with a total of 25 being successfully interviewed. The convenience and snowball sampling for this survey's solicitation effort precludes an ability to calculate survey response rate, because the exact number of beekeepers contacted is not known. Based on subscription rates of electronic listservers such as BEE-L and Catch the Buzz, however, we estimate that over 20,000 beekeepers were contacted (Flottum, 2010). The questions asked are shown in Box 1.

For question one, which asked in which state(s) the respondent kept bees, a list of all US States, the District of Columbia, and an "other" category was provided. Respondents could check more than one option. Those checking "other" were asked to specify the location of their colonies. For the question 9, pertaining to the perceived cause of losses, respondents could choose from a list of common responses from previous survey efforts (vanEngelsdorp et al., 2011a). These included: queen failure; starvation; varroa mites; Nosema disease; small hive beetles; poor wintering conditions; pesticides; weak in the fall; Colony Collapse Disorder (CCD); don't know; did not suffer losses; and other. Those responding "other" were asked to specify their perceived cause of loss. For all other questions, possible

\section{Box 1.}

1. In what state(s) did you keep your colonies in $2010 ?$

2. How many living colonies did you have on 1 October 2010?

3. How many living colonies did you have on 1 April 2011?

4. Did you make splits, increases or buy / sell colonies between 1 October 2010 and 1 April 2011?

5. How many splits, increases, and / or colonies did you make / buy between 1 October 2010 and 1 April 2011?

6. How many splits, increases, and / or colonies did you sell between 1 October 2010 and 1 April 2011?

7. What percentage of the colonies that died between 1 October and 1 April were lost without dead bees in the hive or apiary?

8. What percentage of loss, over this time period, would you consider acceptable?

9. In your opinion, which factor(s) was the main cause(s) of colony death in your operation between 1 October 2010 and 1 April 2011?

10. What percentage of your hives did you send to California for almond pollination?

11. How many times, on average, did you move your colonies last year?

12. Would you be willing to be contacted by our survey team in order to participate in other honey bee related surveys and/or to validate this survey and to receive a summary of survey results?

answers were not provided and beekeepers were expected to type out answers in the fields provided.

This survey design and distribution was approved by the University of Nebraska-Lincoln Institutional Review Board (UNLIRB \#200608523 EP) to ensure compliance with US Federal Law regarding research with human subjects. As in previous years, to help ensure loss estimates could be compared internationally, core survey questions were in keeping with efforts of Working Group 1 of COLOSS, an international network of honey bee researchers dedicated to the prevention of honey bee COlony LOSSes (Nguyen et al., 2011; van der Zee, 2012). 
Survey responses were solicited and collected between 1 and 18 April 2011. Once complete, the data were edited to permit processing (i.e. changing text to numbers (e.g. 2 instead of two) where appropriate). Filters were also developed to exclude from the analysis responses such as surveys with incomplete answers or those that were obviously duplicate answers. As in previous efforts, beekeepers were assigned to operational size groups by the following criteria; beekeepers managing 50 or fewer colonies were classified as "backyard beekeepers"; those managing between 51 and 500 colonies were classified as "sideline beekeepers"; and those managing 501 or more colonies were classified as "commercial beekeepers".

\section{Calculations and statistical analysis}

Total and average colony losses were calculated in keeping with the approach and standard outlined by vanEngelsdorp et al. (2011b). Confidence Interval (CI) calculations for total losses were conducted using R (R Development Core Team, 2009; code provided by Y Brostaux and B K Nguyen). The mean percentage of individual operation colony loss was calculated to determine the average loss among all respondents and subgroups. Average loss $95 \%$ Confidence Intervals (95\% CI) were calculated using the statistical program SAS JMP (SAS, 2007) as outlined in vanEngelsdorp et al. (2011b).

Unlike in previous years, total loss values were only calculated and reported for the entire nation and individual states with sufficient response rates to permit reporting. Whilst total loss values are the most accurate representation of losses suffered within a region, they are biased by overly representing the losses of larger operations because they manage more colonies. Total loss calculations were not therefore calculated for sub-classifications other than those based on region. Instead, potential differences between sub-groups of the responding beekeepers were explored by calculating and comparing average operational losses using the Kruskal-Wallis rank sum test.

When calculating losses in individual states, colonies belonging to operations which managed colonies in more than one state were counted multiple times; once in each listed state. This same practice is used by the National Agricultural Statistics Service when calculating the number of honey-producing colonies in each state (USDA-NASS, 2009). Responses for groups containing fewer than nine respondents are not reported, to protect the privacy of respondents. The total number of colonies lost with the symptom of "no dead bees in the hive or apiary" was calculated for individual operations by multiplying the number of colonies lost in an operation by the reported percentage lost without dead bees. The ratios of beekeepers grouped by operation size who suffered losses with the symptom of "no dead bees in the hive or apiary" were compared using the Chi square test.

\section{Results}

\section{Average and total losses}

\section{National losses}

The survey recorded 5,770 responses, of which 36 were duplicates and 51 did not reside in the US so were removed. An additional 242 respondents did not provide all the information needed to quantify overwintering losses. The remaining 5,441 respondents managed a total of 309,200 living colonies on 1 October 2010, representing $11.5 \%$ of the estimated 2.68 million honey-producing colonies being managed in the US in 2010 (USDA-NASS, 2010). These same 5,411 beekeepers reported 267,089 living colonies on 1 April 2011. When colonies that were made, bought $(n=80,707)$ or sold $(n=8,670)$ are factored into the calculation, the 5,411 respondent beekeepers lost an average of $38.4 \%$ (95\% CI: $37.4-39.4 \%$ ) of their colonies, while the total loss suffered by this group was $29.9 \%$ ( $95 \%$ CI: $29.2-30.4 \%$ ). One-third of responding beekeepers, all of whom were backyard beekeepers, reported no winter losses.

\section{Losses by state}

There was considerable variation in both the average (Table 1; Fig. 1) and total (Table 1; Fig. 2) losses suffered by beekeepers operating in different states. The percentage of colonies and operations in any given state which operated exclusively in that state is summarized (Table 1). As outlined above, operations managing bees in more than one state had their responses reported in all states in which they operated. Some caution is therefore needed when comparing state colony losses where a large proportion of the colonies are managed by beekeepers with bees in several states.

\section{Losses by operation classification}

Average losses suffered by commercial beekeepers tended to be lower than those suffered by sideline and backyard beekeepers, but this difference was not significant ( $P=0.25$, Table 2$)$.

Two percent of survey respondents reported maintaining colonies in more than one state. Although numerically lower, there was no statistical difference $(P=0.58)$ in the average loss experienced by those beekeepers who maintained colonies in more than one state (30.4\%; 95\% CI: $23.6-37.3 \% ; n=114$ ) when compared to those who maintained colonies exclusively in one state $(38.5 \%$; $95 \% \mathrm{CI}$ : $37.6-39.6 \% ; n=5,327$ )

Only $1.6 \%$ of respondents indicated that they utilized at least some of their operation for almond pollination during the survey period. On average, beekeepers pollinating almonds moved $83.6 \pm$ $2.8 \%$ of their colonies into the almond orchards. The average loss experienced by beekeepers who moved colonies into almond orchards 
Table 1. The number of operations and colonies contributing to the percentage of average and total losses by state (also summarized in Fig. 1 and Fig. 2) and the percentage of operations and colonies in each state that operated exclusively in that state. Operations reporting managing colonies in more than one state have had all of their colonies counted in all states in which they reported managing colonies. Results for states with fewer than nine respondents are not presented.

\begin{tabular}{|c|c|c|c|c|c|c|}
\hline State & $\begin{array}{c}\text { No. } \\
\text { Operations }\end{array}$ & $\begin{array}{c}\text { Operations } \\
\text { exclusively } \\
\text { in state (\%) }\end{array}$ & $\begin{array}{l}\text { Total No. } \\
\text { Colonies }\end{array}$ & $\begin{array}{l}\text { Colonies } \\
\text { exclusively in } \\
\text { state (\%) }\end{array}$ & $\begin{array}{c}\text { Average Loss } \\
\text { mean }(95 \% \mathrm{CI})\end{array}$ & $\begin{array}{c}\text { Total Loss } \\
\text { mean }(95 \% \mathrm{CI})\end{array}$ \\
\hline Alabama & 35 & 97.1 & 514 & 98.1 & $15.2(7.2-23.2)$ & $11.3(6.84-18)$ \\
\hline Alaska & 3 & & & & & \\
\hline Arizona & 7 & & & & & \\
\hline Arkansas & 43 & 95.3 & 305 & 96.1 & $22.4(13.4-31.3)$ & $30.2(22.8-38.8)$ \\
\hline California & 328 & 82.6 & 310650 & 14.1 & $39(35.1-42.9)$ & $27.2(25-29.4)$ \\
\hline Colorado & 137 & 97.1 & 1156 & 82.5 & $37.7(31.9-43.5)$ & $53.4(48.5-58.3)$ \\
\hline Connecticut & 102 & 95.1 & 906 & 57.8 & $51.0(43.8-58.2)$ & $46.6(41.2-52.1)$ \\
\hline Delaware & 15 & 93.3 & 97 & 91.8 & $32.2(11.5-52.9)$ & $58.8(37.7-77.1)$ \\
\hline Florida & 133 & 93.2 & 38242 & 6.8 & $25.6(20.5-30.7)$ & $40.32(37-43.8)$ \\
\hline Georgia & 143 & 93.7 & 8270 & 19.4 & $28.1(22.9-33.3)$ & $63.93(58.6-69)$ \\
\hline Hawaii & 42 & 100.0 & 5520 & 100.0 & $44.6(33.0-56.2)$ & $7.7(3.8-15.3)$ \\
\hline Idaho & 27 & 81.5 & 10033 & 1.0 & $30.4(16.9-43.9)$ & $5.8(3.9-8.4)$ \\
\hline Illinois & 136 & 97.8 & 1102 & 95.7 & $54.9(48.5-61.3)$ & $45(39.8-50.3)$ \\
\hline Indiana & 151 & 100.0 & 1228 & 100.0 & $41.9(35.9-47.9)$ & $37.5(34-41.1)$ \\
\hline Iowa & 28 & 96.4 & 765 & 99.7 & $45.1(31.7-58.5)$ & $66(57.4-73.7)$ \\
\hline Kansas & 21 & 95.2 & 401 & 98.0 & $22.1(8.9-35.3)$ & $14.5(9.6-21.1)$ \\
\hline Kentucky & 55 & 98.2 & 991 & 97.0 & $28.3(18.9-37.7)$ & $30.6(24.5-37.4)$ \\
\hline Louisiana & 18 & 94.4 & 3515 & 19.8 & $17.1(4.7-29.5)$ & $25.1(22.4-28)$ \\
\hline Maine & 105 & 95.2 & 22764 & 2.9 & $48.8(41.2-56.4)$ & $45.9(41.8-50.2)$ \\
\hline Maryland & 172 & 97.7 & 1622 & 95.1 & $37.2(32.1-42.3)$ & $49.5(44.5-54.4)$ \\
\hline Massachusetts & 219 & 95.4 & 19931 & 11.9 & $46.3(41.3-51.2)$ & $34.7(33.2-36.2)$ \\
\hline Michigan & 278 & 98.2 & 22631 & 21.0 & $62.7(58.3-67.0)$ & $34.8(31.4-38.4)$ \\
\hline Minnesota & 55 & 83.6 & 128099 & 11.4 & $51.7(41.9-61.4)$ & $32.1(28.5-35.7)$ \\
\hline Mississippi & 16 & 68.8 & 118909 & 0.1 & $12.8(0-25.6)$ & $26.5(22.4-31)$ \\
\hline Missouri & 161 & 100.0 & 2441 & 100.0 & $26(21.1-30.9)$ & $29.0(24.4-33.2)$ \\
\hline Montana & 26 & 73.1 & 51637 & 0.2 & $50.6(34.4-66.8)$ & $20.4(14.4-28)$ \\
\hline Nebraska & 16 & 81.3 & 95800 & 0.1 & $29.5(16.9-42.1)$ & $29.3(25.9-32.9)$ \\
\hline Nevada & 6 & & & & & \\
\hline New Hampshire & 84 & 97.6 & 902 & 98.7 & $55.4(47.1-63.6)$ & $31.4(25.2-38.2)$ \\
\hline New Jersey & 110 & 90.0 & 2366 & 29.7 & $30.9(24.1-37.6)$ & $28.7(25.3-32.2)$ \\
\hline New Mexico & 24 & 95.8 & 188 & 97.3 & $19(5.0-32.9)$ & $11.7(6.8-19.3)$ \\
\hline
\end{tabular}


Table 1 Cont'd. The number of operations and colonies contributing to the percentage of average and total losses by state (also summarized in Fig. 1 and Fig. 2) and the percentage of operations and colonies in each state that operated exclusively in that state. Operations reporting managing colonies in more than one state have had all of their colonies counted in all states in which they reported managing colonies. Results for states with fewer than nine respondents are not presented.

\begin{tabular}{|c|c|c|c|c|c|c|}
\hline State & $\begin{array}{c}\text { No. } \\
\text { Operations }\end{array}$ & $\begin{array}{c}\text { Operations } \\
\text { exclusively } \\
\text { in state (\%) }\end{array}$ & $\begin{array}{c}\text { Total No. } \\
\text { Colonies }\end{array}$ & $\begin{array}{l}\text { Colonies } \\
\text { exclusively in } \\
\text { state }(\%)\end{array}$ & $\begin{array}{c}\text { Average Loss } \\
\text { mean }(95 \% \mathrm{CI})\end{array}$ & $\begin{array}{c}\text { Total Loss } \\
\text { mean }(95 \% \mathrm{CI})\end{array}$ \\
\hline New York & 217 & 92.2 & 11737 & 18.4 & $44.1(39.3-48.8)$ & $58.5(55.0-62.0)$ \\
\hline North Carolina & 616 & 96.4 & 7939 & 74.9 & $25.7(23.2-28.1)$ & $24.7(23.1-26.3)$ \\
\hline North Dakota & 21 & 38.1 & 162799 & 0.3 & $33.9(20.4-47.3)$ & $24.6(20.2-29.5)$ \\
\hline Ohio & 242 & 100.0 & 1449 & 100.0 & $38.6(33.9-43.2)$ & $42.6(38.6-46.7)$ \\
\hline Oklahoma & 31 & 93.5 & 793 & 98.5 & $29.2(16.8-41.5)$ & $16.5(8.4-29.9)$ \\
\hline Oregon & 179 & 92.2 & 20138 & 5.8 & $29.7(24.7-34.6)$ & $9.5(0.08-10.7)$ \\
\hline Pennsylvania & 431 & 98.4 & 9056 & 42.3 & $49(45.2-52.7)$ & $67.1(64.2-69.8)$ \\
\hline Rhode Island & 66 & 95.5 & 226 & 94.7 & $46.2(35.9-56.5)$ & $48.6(40.3-57.2)$ \\
\hline South Carolina & 81 & 88.9 & 3741 & 18.0 & $20.1(15.2-24.9)$ & $39.1(34.9-43.3)$ \\
\hline South Dakota & 18 & 77.8 & 92218 & 0.1 & $22.9(7.8-38.0)$ & $31.7(30.7-32.8)$ \\
\hline Tennessee & 90 & 94.4 & 732 & 83.6 & $21.7(15.5-27.9)$ & $22.3(17.3-28.3)$ \\
\hline Texas & 76 & 85.5 & 138338 & 1.2 & $20.3(14.6-25.9)$ & $25.8(23.6-28.2)$ \\
\hline Utah & 117 & 98.3 & 5389 & 45.1 & $32.9(26.9-38.9)$ & $29.5(26.6-32.4)$ \\
\hline Vermont & 119 & 95.8 & 1591 & 93.8 & $41.2(34.6-47.8)$ & $26.7(21.8-32.3)$ \\
\hline Virginia & 406 & 95.8 & 4450 & 57.7 & $33.7(30.3-37.2)$ & $31.1(28.8-33.5)$ \\
\hline Washington & 150 & 94.7 & 27472 & 5.3 & $41.6(35.6-47.6)$ & $23.4(20.2-27)$ \\
\hline $\begin{array}{l}\text { Washington, } \\
\text { D.C. }\end{array}$ & 3 & & & & & \\
\hline West Virginia & 55 & 90.9 & 588 & 82.7 & $49.2(38.7-59.7)$ & $54.8(45.2-64.0)$ \\
\hline Wisconsin & 126 & 96.0 & 3665 & 97.5 & $57.7(51.3-64.1)$ & $66.3(61.6-70.7)$ \\
\hline Wyoming & 8 & & & & & \\
\hline
\end{tabular}

(31.6\%; 95\% CI: $23.4-39.8 \% ; n=79)$ was not significantly different from beekeepers whom did not (38.9\%; $95 \%$ CI: 37.9 $40.0 \% ; n=4,931 ; P=0.77)$.

Only $1.7 \%$ of responding beekeepers indicated that they had transported a majority of their colonies across state lines during the preceding year. Beekeepers who moved their colonies lost, on average, fewer colonies (32.9\%; 95\% CI: $25.1-40.7 \% ; n=88)$, but the difference was not significant $(P=0.74)$ when compared to those that did not move colonies (38.9\%; 95\% CI: $37.9-40.6 ; n=4,914$ ).

One of the defining characteristics of CCD is the complete absence of dead bees in the hive or apiary (vanEngelsdorp et al., 2009). This survey was not meant to differentiate between colonies lost to CCD and other conditions that may cause colony loss with this symptom. Of those respondents who experienced at least some loss, and answered this question, $23 \%$ (of $n=3,610$ respondents) indicated that at least some of their dead colonies were found without dead bees in the hive or apiary. Those reporting losses in addition to the no dead bees symptom reported higher average losses (62.3\%; 95\% CI: $60.2-64.4 \% ; n=828$ ) when compared to those who reported losses without the symptom of no dead bees (56.5\%; 95\% CI: 55.4 $57.7 \% ; n=2,782 ; \mathrm{P}<0.0001)$. In all, of the 114,118 colonies reported to have died over this survey period, an estimated $26.3 \%$ ( $n=30,135$ ) died with the symptom "no dead bees in the hive or apiary". Of beekeepers who reported suffering losses, commercial beekeepers were 2.6 and 1.4 times more likely to report having some of their dead colonies die with an absence of dead bees than were backyard and sideline beekeepers $\left(X^{2}=19.0 ; P<0.001\right.$ and $X^{2}=$ 18.7; $\mathrm{P}<0.001$, respectively). 


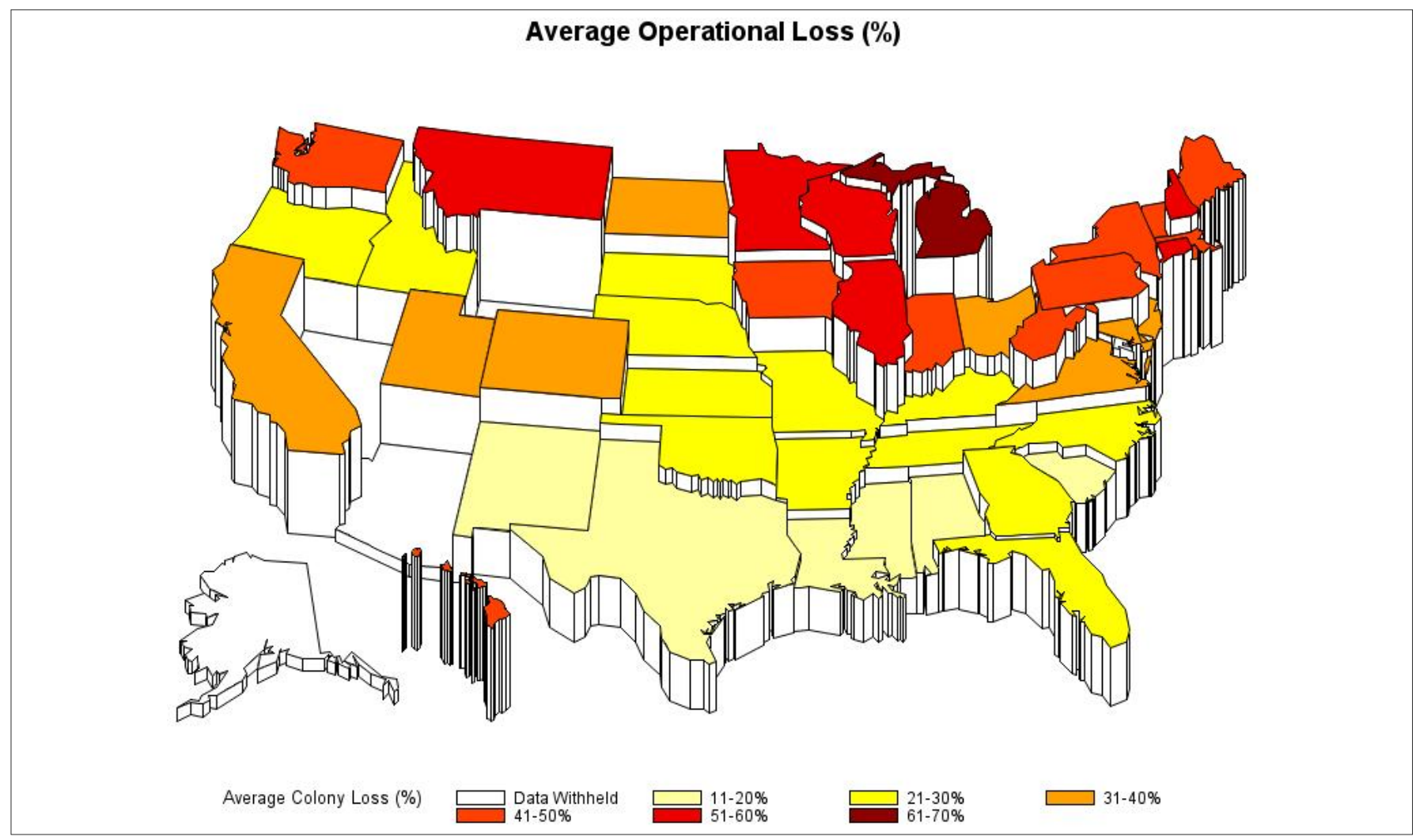

Fig. 1. Average percentage of loss in each operation by state. Operations who reported managing colonies in more than one state had their losses included in all of the states in which they reported managing colonies (see Table 1). States which had fewer than nine respondents (data withheld) are not included.

\section{Total Colony Loss (\%)}

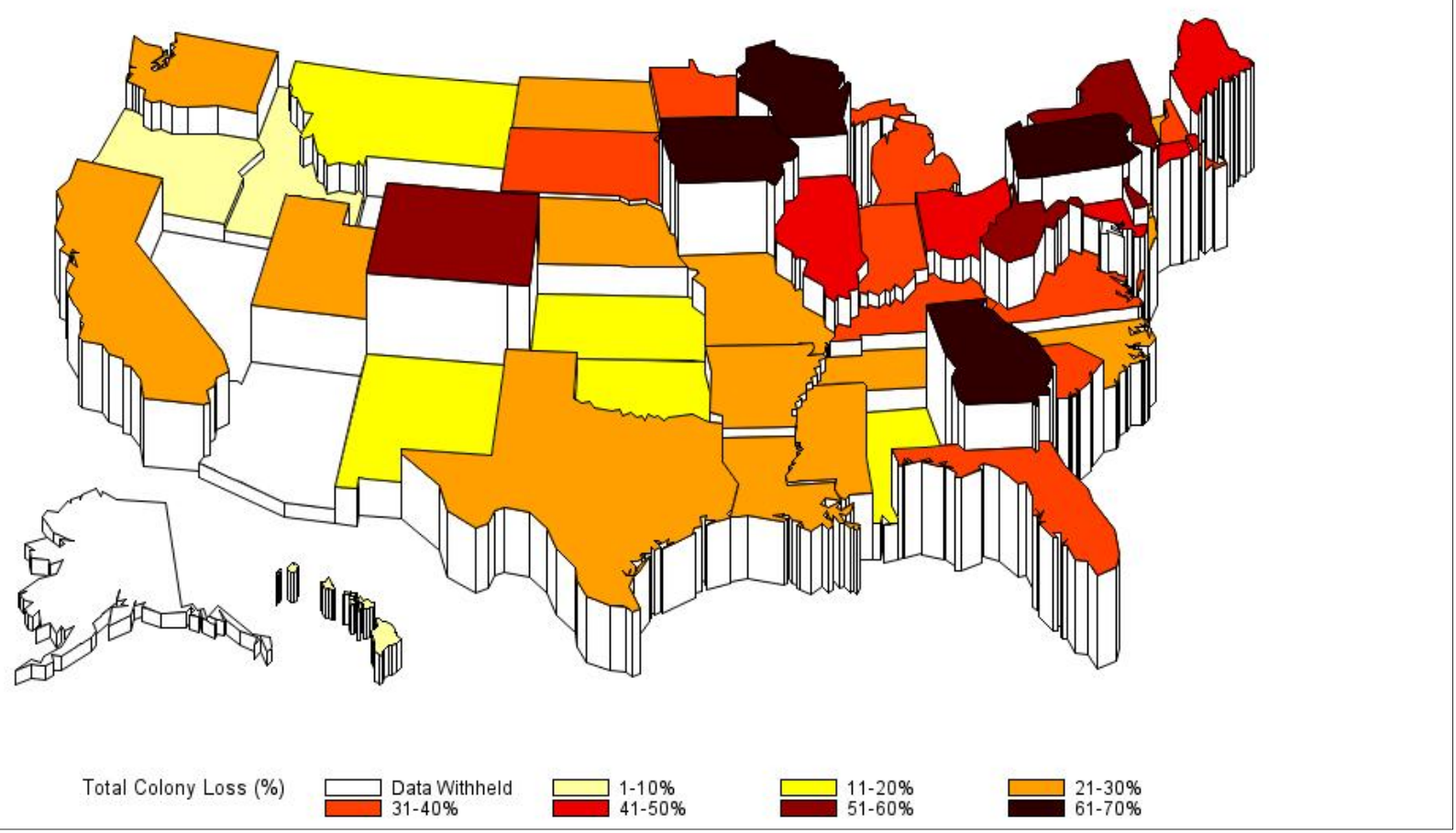

Fig. 2. Total percentage of colony loss by state. Operations who reported managing colonies in more than one state had their losses included in all of the states in which they reported managing colonies (see Table 1). States which had fewer than nine respondents (data withheld) are not included. 
Table 2. Average losses suffered by beekeepers grouped by the size of their operation.

\begin{tabular}{|l|c|c|}
\hline Operation Type & Respondents & $\begin{array}{c}\text { Average Loss } \\
\text { Mean (95\% CI) }\end{array}$ \\
\hline Backyard & 5220 & $38.5(37.5-39.5)$ \\
\hline Sideline & 163 & $37.4(31.7-43.2)$ \\
\hline Commercial & 58 & $28.3(18.7-38.0)$ \\
\hline
\end{tabular}

Table 3. Average losses reported by beekeepers who listed one or more factors as the leading cause of mortality in their beekeeping operation as compared to responding beekeepers not listing that particular cause as important. *Excludes those who indicated they suffered no loss as well as those who indicated they did not know which factors contributed to their losses.

\begin{tabular}{|c|c|c|c|c|c|c|}
\hline & & Factor Listed & & Not Listing Factor ${ }^{*}$ & \multicolumn{2}{|c|}{ Kruskal Wallis Rank SumTest } \\
\hline Factor & $n$ & $\begin{array}{l}\text { Avg Loss \% } \\
(95 \% \mathrm{CI})\end{array}$ & $n$ & $\begin{array}{l}\text { Avg Loss \% } \\
(95 \% \mathrm{CI})\end{array}$ & $x^{2}$ & $\mathbf{P}$ \\
\hline Starvation & 1053 & $53.7(51.8-55.7)$ & 1629 & $54.4(52.8-56.0)$ & 0.16 & 0.6822 \\
\hline Weak in the fall & 921 & $52.8(50.7-54.9)$ & 1761 & $54.8(53.3-56.4)$ & 1.78 & 0.1840 \\
\hline Poor winter & 833 & $64.3(62.2-66.5)$ & 1849 & $49.7(49.1-51.0)$ & 118.8 & 0.0001 \\
\hline Queen & 655 & $47.5(45.0-50.0)$ & 2027 & $54.4(52.8-56.0)$ & 37.5 & 0.0001 \\
\hline Varroa & 534 & $59.5(56.8-62.3)$ & 2148 & $52.8(51.4-54.2)$ & 18.8 & 0.0001 \\
\hline Nosema & 317 & $55.9(52.3-59.5)$ & 2365 & $53.9(52.6-55.3)$ & 1.14 & 0.2843 \\
\hline CCD & 199 & $65.1(60.6-69.6)$ & 2483 & $53.3(52.0-54.5)$ & 23.6 & 0.0001 \\
\hline Pesticides & 125 & $58.9(53.1-64.6)$ & 2557 & $53.9(52.7-55.2)$ & 2.51 & 0.1134 \\
\hline Small hive beetle & 96 & $63.7(57.1-70.2)$ & 2586 & $53.8(52.5-55.0)$ & 8.29 & 0.0040 \\
\hline
\end{tabular}

\section{Acceptable losses}

Surveyed beekeepers were asked "What percentage of loss, over this time period, would you consider acceptable?" On average, responding beekeepers $(n=4,425)$ reported that a winter loss of $13.2 \%$ (95\% CI: $12.7-13.7 \%$ ) was considered acceptable. Sixty percent of responding beekeepers experienced actual losses higher than they considered acceptable. The average losses experienced by this group were higher than the average losses experienced by those who had losses below what they considered acceptable (60.0\%; 95\% CI: 59.1 $-61.0 \%$ vs. 4.0\%; 95\% CI: $2.5-5.3 \%$, respectively; P < 0.0001).

\section{Perceived causes of losses}

A total of 4,781 respondents answered the question "To what do you attribute the cause of death for the colonies that died?" Of these, $70 \%$ experienced at least some loss. Twenty-one percent of these 3,389 beekeepers indicated that they did not know the cause of death of the colonies in their operation that had died. Beekeepers who indicated that they did not know the cause of mortality in their operation lost, on average, $64.4 \%$ (95\% CI: $61.9-66.7 \%$; $n=707)$, more than those who lost colonies and identified at least one reason for their loss (54.1\%; 95\% CI: $52.4-55.3 \% ; n=2,682$ ). Among beekeepers who experienced losses and indicated at least one reason why they lost colonies, the top five most frequent reasons given, in order, were: starvation; weak colonies in the fall; poor wintering conditions; poor queens; and varroa mites (Table 3). Respondents who suspected varroa mites, small hive beetles, poor wintering conditions, and / or CCD as responsible for their losses experienced higher average losses when compared to beekeepers who suspected other factors. Conversely, those respondents who suspected poor queens as the major cause of their losses suffered lower average losses than those who did not suspect queens as responsible for their losses (Table 3).

\section{Discussion}

This survey records the fifth consecutive year of overwintering colony losses well above the level US beekeepers consider acceptable. Survey respondents reported total colony losses of $29.9 \%$ and average operational losses of $38.4 \%$. This is the fifth year that average losses of $30 \%$ or more have been recorded. Should these survey results be representative of national losses, between 782,560 and 814,720 colonies were lost in the US over the winter of 2010-11. Caution should however be used when interpreting this projection, as 
this survey cannot be considered to be representative of all beekeepers. The email solicitation of beekeeper respondents probably biased participation to the subgroup of beekeepers that are internet literate. As no comprehensive census of US beekeepers exists, we have no way to quantify and adjust for this potential bias.

Larger operations were more likely to report having some of the colonies in their operation die with the symptom of "no dead bees in the hive or apiary". This symptom is one of the defining characteristics of CCD, and as in previous years, those losing some of their colonies to this condition experienced greater total losses than those not reporting the condition.

In summary, this national survey effort, in its fifth consecutive year, recorded high rates of mortality in overwintering colonies in the US. Losses suffered by smaller-sized operations were higher than the losses suffered by larger operations, even though larger operations were more likely to report having some of their losses occur in the absence of dead bees in the hive or apiary; a defining symptom of CCD. These results all point to the continuing need to record colony losses on an annual basis. These continuing efforts should also strive to improve survey methods to ensure a more representative beekeeping population is sampled and accounted for. Concentrated efforts aimed at understanding the underlying causes of these losses are also needed.

\section{Acknowledgements}

We thank all respondents, including those contacted by phone and email for their participation. We thank Vic Levi, Nathan Rice, Karen Roccasecca, Bart Smith, Jennie Spitzinger and Linda Wertz for making the survey calls to numerous beekeepers, as well as the many beekeeping organizations, industry leaders and beekeeping clubs that forwarded our appeal for participation emails. Thank you also to the Apiary Inspectors of America, Bee Culture magazine and American Bee Journa/ for sending out participation requests to their online audiences. This project was funded by a CAP grant from USDA-NIFA: the Bee Informed Partnership and includes, in addition to several of the authors, K Baylis, J H Connell, K S Delaplane, S Donohue, W Esaias, B Gross, R Rose, J Skinner, M Spivak, D R Tarpy and J T Wilkes.

\section{References}

CARON, D M; BURGETT, M; RUCKER, R; THURMAN, W (2010) Honey bee colony mortality in the Pacific Northwest, winter 2008/2009. Americian Bee Journal 150: 265-269.
CURRIE, R W; PERNAL, S F; GUZMÁN-NOVOA, D E (2010) Honey bee colony losses in Canada. Journal of Apicultural Research 49(1): 104-106. DOI: 10.3896/IBRA.1.49.1.18

DABERKOW, S; KORB, P; HOFF, F (2009) Structure of the US beekeeping industry: 1982-2002. Journal of Economic Entomology 103: 868-886. DOI: 10.1603/029.102.0304

FLOTTUM, K (2010) Inner cover. Bee Culture 138: 10.

NEUMANN, P; CARRECK, N L (2010). Honey bee colony losses.

Journal of Apicultural Research 49(1): 1-6. DOI: 0.3896/

IBRA.1.49.1.01

NGUYEN, B K; MIGNON, J; LAGET, J; DE GRAAF, D C; JACOBS, F J; VANENGELSDORP, D; BROSTAUX, Y; SAEGERMAN, C; HAUBRUGE, E (2010) Honey bee colony losses in Belgium during the 2008-2009 winter. Journal of Apicultural Research 49(3): 333339. DOI: $10.3896 /$ IBRA.1.49.4.07

NGUYEN, B K; VAN DER ZEE, R; VEJSN/ES, F; WILKINS, S; LE CONTE, Y; RITTER, W (2010) COLOSS Working Group 1: monitoring and diagnosis. Journal of Apicultural Research 49(1): 97-99. DOI: 10.3896/IBRA.1.49.1.15

POTTS, S G; ROBERTS, S P M; DEAN, R; MARRIS, G; BROWN, M A; JONES R; NEUMANN, P; SETTELE, J (2010). Declines of managed honey bees and beekeepers in Europe. Journal of Apicultural Research 49(1): 15-22. DOI: 10.3896/IBRA.1.49.1.02

R DEVELOPMENT CORE TEAM (2009) R: A language and environment for statistical computing. R Foundation for Statistical Computing, Vienna, Austria. ISBN 3-900051-07-0, URL http://www.R-project.org SAS (2007) JMP computer program. Cary, NC, USA.

(USDA-NASS) UNITED STATES DEPARTMENT OF AGRICULTURE NATIONAL STATISTICS SERVICE (2009) Honey. Department of Agriculture; Washington DC, USA. 6 pp.

(USDA-NASS) UNITED STATES DEPARTMENT OF AGRICULTURE NATIONAL STATISTICS SERVICE (2010) Honey. Department of Agriculture; Washington DC, USA. 6 pp.

(USDA-NASS) UNITED STATES DEPARTMENT OF AGRICULTURE NATIONAL STATISTICS SERVICE (2011) Honey. Department of Agriculture; Washington DC, USA. 6 pp.

VAN DER ZEE, R; PISA, L; ANDONOV, S; BRODSCHNEIDER, R; CHARRIÈRE, J D; CHLEBO, R; COFFEY, M F; CRAILSHEIM, K; DAHLE, B; GAJDA, A; GRAY, A; DRAZIC, M M; HIGES, M; KAUKO, L; KENCE, A; KENCE, M; KEZIC, N; KIPRIJANOVSKA, H; KRAL, J; KRISTIANSEN, P; HERNANDEZ, R M; MUTINELLI, F; NGUYEN, B K; OTTEN, C; ÖZKIRIM, A; PERNAL, S F; PETERSON, M; RAMSAY, G; SANTRAC, V; SOROKER, V; TOPOLSKA, G; UZUNOV, A; VEJSN/ES, F; WEI, S; WILKINS, S (2012) Managed honey bee colony losses in Canada, China, Europe, Israel and Turkey, for the winters of 2008-9 and 2009-10. Journal of Apicultural Research 51(1): 100-114. DOI: 10.3896/IBRA.1.51.1.12 
VANENGELSDORP, D; MEIXNER, M D (2010) A historical review of managed honey bee populations in Europe and the United States and the factors that may affect them. Journal of Invertebrate Pathology 103: S80-S95. DOI: 10.1016/j.jip.2009.06.011

VANENGELSDORP, D; UNDERWOOD, R; CARON, D; HAYES, J Jr (2007) An estimate of managed colony losses in the winter of 2006-2007: a report commissioned by the Apiary Inspectors of America. American Bee Journal 147: 599-603.

VANENGELSDORP, D; HAYES, J Jr; UNDERWOOD, R M; PETTIS, J (2008) A survey of honey bee colony losses in the U.S., Fall 2007 to Spring 2008. PLOS ONE 3: e4071. DOI: $10.1371 /$ journal.pone.0004071

VANENGELSDORP, D; EVANS, J D; SAEGERMAN, C; MULLIN C; HAUBRUGE, E; NGUYEN, B K; FRAZIER, M; FRAZIER, J; COXFOSTER, D; CHEN, Y; UNDERWOOD, R; TARPY, D R; PETTIS, J S (2009) Colony Collapse Disorder: A descriptive study. PloS ONE 4: e6481. DOI:10.1371/journal.pone.0006481
VANENGELSDORP, D; HAYES, J JR; UNDERWOOD, R M; PETTIS, J S (2010) A survey of honey bee colony losses in the United States, fall 2008 to spring 2009. Journal of Apicultural Research 49(1): 714. DOI: $10.3896 /$ IBRA.1.49.1.03

VANENGELSDORP, D; HAYES, J JR; UNDERWOOD, R M; CARON, D; PETTIS, J (2011a) A survey of managed honey bee colony losses in the USA, fall 2009 to winter 2010. Journal of Apicultural Research 50(1): 1-10. DOI: 10.3896/IBRA.1.50.1.01 VANENGELSDORP, D; BRODSCHNEIDER, R; BROSTAUX, Y; VAN DER ZEE, R; PISA, L; UNDERWOOD, R; LENGERICH, E J; SPLEEN, A; NEUMANN, P; WILKINS, S; BUDGE, G E; PIETRAVALLE, S; ALLIER, F; VALLON, J; HUMAN, H; MUZ, M; LE CONTE, Y; CARON, D; BAYLIS, K; HAURBUGE, E; PERNAL, S; MELATHOPOULOS, A; SAEGERMAN, C; PETTIS, J S; NGUYEN, B K (2011b) Calculating and reporting managed honey bee colony losses. In Sammataro, D; Yoder, J [Eds] Honey bee colony health: challenges and sustainable solutions. CRC Press; USA. pp. 237-244. 